\title{
Influence of post-hatch starvation on broiler chick's productivity
}

\author{
${ }^{1}$ Obun, C. O. and ${ }^{2}$ P. O. Osaguona \\ ${ }^{I}$ Departmen of Animal Production, Faculty of Agriculture and life science, PMB 1020, Federal University \\ Wukari, Taraba State \\ ${ }^{2}$ Department of Wildlife and Ecotourism,PMB 268, Federal College of Wildlife Management, New Bussa, Niger \\ State
}

\begin{abstract}
The effect of post hatch starvation on growth rate, feed intake, feed conversion ratio, protein efficiency ratio and nutrient digestibility coefficient was evaluated in broiler chicks. One hundred and eighty "Sayed" day-old broiler chickens were placed in six treatments with three replications of 10 chickens each. The experiment was arranged in a complete random design (CRD) at 12, 24, 36, 48, 60 and 72 hours delay access to feed as treatments. Birds subjected to fasting at 12, 24 and 36h showed no significant $(P>0.05)$ differences in body weight, weight gain, feed intake, feed conversion and protein efficiency ratios. Body weight increased significantly $(P<0.05)$ at 12,24 and $36 \mathrm{~h}$ compared with those at 48,60 and $72 \mathrm{~h}$ delayed access to feed. At 7 days of age, the nutrient digestibility coefficient of dry matter (DM), crude protein $(C P)$, crude fibre $(C F)$, ash and nitrogen free extracts (NFE) was significantly $(p<0.05)$ better at 12, 24 and 36h compared with those at 48, 60 and $72 \mathrm{~h}$. At 28 day of age, the results of the digestibility coefficient of birds at 12, 24 and $36 \mathrm{~h}$ feed holding period was similar $(p>0.05)$ for DM, $C P$ and $C F$ but significantly $(P<0.05)$ differed from those on 48,60 and $72 h$. The EE, ash and NFE were similar $(P>0.05)$ across the treatments with improved values in birds with decreasing starved period. The results of this study revealed that delayed access to feed has adverse effects on broiler performance. It recommended that a source of energy in the hatching basket or during transportation be provided to chicks to reduce starvation.
\end{abstract}

Key words: Post-hatch starvation, feeding, performance, digestibility, broiler chicken

\section{Introduction}

Delay before feed access is considered to be the time spent in the hatchery after hatch added to transportation time to the broiler farm. Growth of broilers during the first days post-hatch is of paramount importance for ultimate performance of poultry reared for meat. Several authors $[1,2,3,4,5]$ have reported that delayed access to feed decreased broiler post-hatch performance. During the first week of life allometric growth is maximal and the chick multiplies initial body weight 4 to 5 -fold. In commercial operations, a large proportion of chicks remain without feed for more than $36 \mathrm{hrs}$ after removal from the incubator as placement on the farm is frequently delayed because of hatchery processing and transportation [1]. In some cases the chicks have to be vent-sexed and vaccinated, which may extend the off-feed time. Thus, in practice, newly hatched chicks spend substantial time without access to feed or water (48-72 h), causing poor viability and slow growth [5]. Delayed feeding was found to be the main factor affecting growth in broiler chickens as the chicks must have exhausted up to $94 \%$ of the yolk reserves initially available at hatch [6]. In a study conducted by [1], it was observed that post-hatch deprivation of feed and water for $48-72 \mathrm{~h}$ reduced body weight of broilers by $7.8 \%$ over those fed immediately after hatch.

Body weight of poultry has been reported to decrease linearly after hatch in the hatching trays between 0.14 and $0.17 \mathrm{~g} \mathrm{~h}^{-1}$ [7]. Therefore, it is extremely important for the chicks to consume nutrients as close to hatch as possible. Early access to feed and water stimulates rapid growth of the gastro-intestinal tract (GIT) and its absorptive capacity, improve chick's immune system [8], faster utilization of yolk suck [9] and improves gut integrity and subsequent performance $[1,9,11]$. Hence this study was designed to assess effect of delayed access to feed on broiler chicks' performance.

\subsection{Study site}

\section{Materials and Methods}

This study was conducted in the poultry unit of Teaching and Research Farm of Federal College of Wildlife Management, New Bussa, Niger state.

\subsection{Design and management of birds}

A total of 180 day-old commercial "Sayed" broiler chicks were obtained from Ibadan and were transported to the study area within $8 \mathrm{~h}$ and were divided into six groups (A, B, C, D, E and F), which presents starved for 12, 24, 36, 48, 60 and 72 hours initial feed and water introduction intervals. There was no zero hour 
due to the far distance from the bird's source to the study area. Each group was further divided into three replicates having 10 chicks per replicate in a completely randomized design (CRD). The birds were raised on conventional deep litter system, with open sided house. The composition of the diet is presented in Table 1 . The diet and water were offered ad-libitum to the birds for 28 days. Standard management procedures typical of starting broiler in a tropical environment were strictly applied.

\subsection{Data collection}

The birds were weighed at the beginning of the experiment and subsequently weekly in order to measure average weight. Feed-to-gain ratio was calculated by dividing the average feed intake by the average weight gain, protein efficiency ratios calculated by weight gain divided by daily protein intake while percent mortality was calculated by dividing the number of dead birds by the number of birds started with, all multiplied by hundred. At the 7 and 28 days of age, three birds per treatment were transferred to metabolic cage, fed for three days and slaughtered and faeces collected from the ileal region for determination of nutrient digestibility coefficient.

\subsection{Chemical assay}

The chemical composition of the diets and faecal dropping samples of the mixed faeces of all birds on a treatment were then dried at $65^{\circ} \mathrm{C}$ for 48 hours for analysis of dry matter (DM), crude protein (CP), crude fibre $(\mathrm{CF})$, ether extracts (EE). Ash and nitrogen free extract (NFE) using standard method of [12].

\subsection{Statistical analysis}

The data was statistically analyzed with the standard procedures of analysis of variance (ANOVA), using Completely Randomized Design. Means were compared for significance of differences by least significance differences (LSD) according to [13] method.

\section{Results and Discussion}

The results confirmed that delay in feed access caused weight loss during holding time and depressed growth rate after access to feed (Table 2). The decreased in the initial body weight of chicks is in line with reports by $[1,7,15]$ that body weight of chicks decreased linearly after hatch in the hatching trays between 0.14 and $0.17 \mathrm{~g} \mathrm{~h}^{-1}$ and delaying placement increases this body weight reduction. The body weight (BW), body weight gain (BWG), feed intake (FI), daily feed intake (DFI), feed conversion ratio (FCR) and protein efficiency ratio (PER) decreased with increasing post hatch delayed access to feed.

The BW of birds fed at 12 to $36 \mathrm{~h}$ post hatch were similar $(\mathrm{P}>0.05)$ but significantly $(\mathrm{P}<0.05)$ superior to those on 48-72h fasting (Table 2). The observed lower weight gain in fasted chicks during the fourth week of life is consistent with reports by [5, 15], that delayed access to feed decreased broiler post-hatch performance. The overall adverse effects of delayed in feed access observed in this study are in accordance with the previous observations of $[1,3,16]$, who pointed out that the common practice whereby feed is being first available to chicks one or more days post hatch may depress subsequent development. Lower weight gain exhibited with increasing fasted period (48-72h) could be attributed to lower feed intake and poor development of digestive tract. [17] reported that when feed consumption starts soon after hatch, the nutrients provided by feed are complementary to the yolk nutrients and this will trigger rapid growth rate in birds. Initiation of feed consumption as close to hatch as possible is essential to support early muscle development, which may ultimately affect meat yield.

The poor FCR and PER of birds starved for 48 to $72 \mathrm{~h}$ is inline with earlier findings by [18] that feeding broiler in the first days of life is one of the priority factor that could affect growth, feed efficiency, uniformity and economic benefit. The superior performance in FCR and PER of birds on 12-36h delayed access to feed is in agreement with findings by [19] that nutrient utilization is dependent on digestible and absorption in gastrointestinal tract (G.I.T). This could also be due to an increased enzymes secretion from GIT. The effect of these enzymes on feed digestion and absorption are due to duration of feed which remain in GIT [19]. This was confirmed by [20]. The percentage mortality was high in the treatments with increase feed holding time (Table 2). This result is supported by earlier reports by [21] that chicks delayed access to feed and water experience a decreased yolk nutrient content and increased mortality, which suggests a nutrient deficit in the post hatch bird. The results in Table 3 show the ileal digestibility coefficient of broilers at 7 and 28 days of age. The birds delayed access to feed at 12, 24 and 36h showed better ( $P>0.05)$ digestibility coefficient of dry matter, crude protein, crude fibre, ash and nitrogen free extracts but significantly $(\mathrm{P}<0.05)$ differed from those at 48,60 and 72h. The decreased in nutrient digestibility with increasing delayed access to feed is in agreement with findings by[22] who reported that birds fed immediately after hatching had higher trypsin, amylase and lipase activities in intestinal mucosa, which was correlated to higher intestinal weight and body weight. Also, these authors 
reported that feed intake set off constant secretion of amylase and trypsin, although many studies had indicated that pancreatic enzymes are already in birds' small intestine at embryo phase.

[23] reported that newly hatched chicks have a reserve of pancreatic enzymes produced during embryo growth, but these reserves are not sufficient to substrate hydrolyze in lumen and to maintain the initial concentration, so, these enzyme levels decline just after hatching. The digestibility coefficient increase with increasing age of the birds. The birds on 12, 24 and $36 \mathrm{~h}$ were similar $(\mathrm{P}>0.05)$ for $\mathrm{DM}, \mathrm{CP}$ and $\mathrm{CF}$ but significantly $(\mathrm{P}<0.05)$ differed from those on 48, 60 and 72h. The EE, ash and NFE were similar ( $>0.05)$ across the treatments with improved values in birds with decreasing starved period. This results is in agreement with reports by [22] that the activities of digestive enzymes (units kg ${ }^{-1}$ of body weight), measured in pancreas and in intestinal lumen, increase with age, with maximum values found in pancreas at 8th day after hatching for amylase and lipase, and at 11th day for trypsin and chymotrypsin.

These authors reported that the intestinal contents' maximum activity was observed at 4th day for lipase, at 11th day for trypsin and chymotrypsin, and at 17th day for amylase. Following [24], protein digestion in small intestine increased from $78 \%$ at $4^{\text {th }}$ day to $92 \%$ at $21^{\text {st }}$ day of age. According to [24], fatty acid digestion increased from $82 \%$ at day 4 to $89 \%$ at day 21 after hatching. Lipid metabolism depends on factors, such as the presence of bile salts, pancreatic lipase, fatty acid binding protein, and proper entero-hepatic circulation.

\section{Conclusion}

In conclusion, delayed access to feed adversely affects chicks' performance. Holding feed time for 48 to $72 \mathrm{~h}$ is compensated by increasing the length of time required to reach market weight. The results of this study suggest that the adverse effects of delay access to feed can be reduced by providing a source of energy in the hatching basket or during transportation.

\section{References}

[1]. Noy, Y., and D. Sklan. Different types of early feeding and performance in chicks and poults. J. Appl. Poult. Res. 1999 8:16-24.

[2]. Noy, Y.,A. Geyra, and A. Sklan. The effects of early feeding on growth and small intestinal development in the post hatch poultry. Poult. Sci., 2001, 80: 912-919.

[3]. Gonzales, E., N. Kondo, S. P.B. Saldanha, M. Loddy, C. Careghi, and D. Decuypere,. Performance and physiological parameters of broiler chickens subjected to fasting on the neonatal period. Poult. Sci., 2003, 82:1250-1256.

[4]. Halevy, O., Y., Y. Nadel,, M. Barak, I. Rozenboim,I. and D. Sklan,. Early posthatch feeding stimulates satellite cell proliferation and skeletalmuscle growth in turkey Poults. J. Nutr.133:1376-1382.

[5]. Latour, M. A., E. D. Peebles, C. R. Boyle, and J. D. Brake. 1994.The effects of dietary fat on growth performance, carcass composition, and feed efficiency in the broiler chick. Poult. Sci. . 2003, 73:1362-1369.

[6]. Uni, Z., A.Smirnov. and D. Sklan. Pre- and post hatch development of goblet cells in the broiler small intestine: Effect of delayed access to feed. Poult. Sci. 2003, 82:320-327.

[7]. Pinchasov, Y. and Y. Noy. Early post-natal amylolysis in the gastrointestinal tract of turkey poults (Meleagris gallopavo). Comparative Biochemistry and Physiology, 1994, 106: 221-225.

[8]. Pinchasov, Y. and Y. Noy, Comparison of post hatch holding time and subsequent early performance of broiler chicks and turkey 7. Poults. Br. Poult. Sci., 1993, 34: 111-120.

[9]. Bigot, K., S. Mignon-Grasteau., M. Picard, and S. Tesseraud. Effects of delayed feed intake on body, intestine, and muscle development in neonate broilers. Poult. Sci., .2003, 82:781-788.

[10]. Nir, I. and M. Levanon. Research note: effect of posthatch holding time on performance and on residual yolk and liver composition. Poult. Sci., 1993, 72: 1994-1997.

[11]. Moran, E.T. Effects of egg weight, glucose administration at hatch, and delayed access to feed and water on the Poult at 2 weeks of age. Poult. Sci..,1990, 69:1718-1723.

[12]. Corless, A. B., and J. L. Sell.. The effects of delayed access to feed and water on the physical and functional development of the digestive system of young turkeys. Poult. Sci. 1999, 78:1158-1169.

[13]. A.O.A.C. Official Methods of Analysis of the AOAC (W. Horwitiz, Editor), $18^{\text {th }}$ ed. Association of Official Analytical Chemists, Washington D.C., USA. 2006.

[14]. Steel, R. G. D. and J. H. Torrie. Principles and Procedures of Statistics. A Biometrical Approach. 2nd ed. McGraw-Hill,New York. 1980.

[15]. Saki, A.A. Effect of Post-hatch Feeding on Broiler Performance. International Journal of Poultry Science, (2005, 4 (1): $4-6$.

[16]. Batal, A.B. and C. M. Parsons. Effects of age on nutrient digestibility in chicks fed different diets. Poult. Sci.., 2002a, 81:400-407.

[17]. Geyra, A., Z. Uni and D. Sklan. Enterocyte dynamics and mucosal development in the post hatch chick. Poult. Sci.., 2001, 80:776782 .

[18]. Murakami, H., Y. Akiba, and M. Horiguchi. Energy and protein utilisation in newly-hatched broiler chicks: studies on the early nutrition of poultry. Japan. J. Zootech. Sci.,1988, 59:890-895.

[19]. Turner, K.A.,T. J. Applegate and M. S. Lilburn. Growth and metabolic status of the post hatch poultry following immediate or delayed access to feed. Poult. Sci., 1999, 78: 1537-1580.

[20]. Griffiths, L., S. Leeson and J. D. Summers. Fat Deposition in broilers: Effect of dietary energy to protein balance and early life caloric restriction of productive performance and abdominal fat pad size. Poult. Sci., 1977, 56: 638-646.

[21]. Deaton, J.W. The effects of early feed restriction on broiler performance. Poult. Sci., 1995, 74: 1280-1286

[22]. Vieira, S.L. and E.T. Moran (Jr.) . Effects of delayed placement and used litter on broiler yield. J. Appl.Poult. Res.,1999a, 8: 75-81.

[23]. Sklan, D. and Y. Noy. Hydrolysis and absorption in the small intestines of post hatch chicks. Poultry Science, 2000, Vol.79:13061310pp.

[24]. Nitsan, Z., G. Ben-Avraham, Z. Zoref and I. Nir,. Growth and development of digestive organs and some enzymes in broiler chicks after hatching. Br. $\quad$ Poult. Noy, Y. and D. Sklan. Digestion and absorption in the young chick. Poultry Science,1995,Vol.74, p.366-373, 
Table 1: Composition of experimental starter broiler chicks' diet

\begin{tabular}{ll}
\hline Ingredients (\%) & Composition \\
\hline Maize & 51.00 \\
Corn bran & 10.00 \\
Palm kernel cake & 3.00 \\
Soyabean meal & 14.00 \\
Groundnut cake & 14.00 \\
Fishmeal & 4.00 \\
Bone meal & 3.00 \\
Lysine & 0.25 \\
Methionine & 0.25 \\
Premix* & 0.25 \\
NaCl & 0.25 \\
Determined Analysis & \\
Crude protein(\%) & 22.10 \\
Crude fibre (\%) & 4.03 \\
Metabolizable energy(Kcal/Kg) & 2986.00
\end{tabular}

* To provide the following per kg of diet: Vit. A 10,000iu, 3 iu Vit. D 2000iu, Vit. E 5 , Vit.K 2mg, Riboflavin $4.20 \mathrm{mg}$, Nicotinic acid 20mg, 12 Vit. B $0.01 \mathrm{mg}$, Pantothenic acid 5mg, Folic acid $0.5 \mathrm{mg}$,Choline $3 \mathrm{mg}$, Mg 56mg, Fe 20mg, Cu 10mg,Zn 50mg, Co 125mg and Iodine 0.08mg.

Table 2: Performance of post-hatch broiler chicks delayed access to feed and water

\begin{tabular}{llllllll}
\hline Parameters & \multicolumn{2}{l}{ Treatments (fasted hours) } & & & \\
\cline { 2 - 6 } & $\mathbf{1 2}$ & $\mathbf{2 4}$ & $\mathbf{3 6}$ & $\mathbf{4 8}$ & $\mathbf{6 0}$ & $\mathbf{7 2}$ & SEM \\
\hline $\begin{array}{l}\text { Initial body weight } \\
\text { (g/bird) }\end{array}$ & 40.00 & 40.00 & 39.5 & 37.23 & 35.00 & 34.5. & 0.06 \\
$\begin{array}{l}\text { Final body weight } \\
\text { (g/bird) }\end{array}$ & $573.00^{\mathrm{a}}$ & $572.22^{\mathrm{a}}$ & $557.00^{\mathrm{ab}}$ & $523.14^{\mathrm{b}}$ & $507.32^{\mathrm{c}}$ & $487.65^{\mathrm{c}}$ & 10.30 \\
$\begin{array}{l}\text { Body weight gain } \\
\text { (g/bird) }\end{array}$ & $533.00^{\mathrm{a}}$ & $532.22^{\mathrm{a}}$ & $517.50^{\mathrm{b}}$ & $485.91^{\mathrm{c}}$ & $472.32^{\mathrm{d}}$ & $453.15^{\mathrm{e}}$ & 9.25 \\
$\begin{array}{l}\text { Daily weight gain } \\
\text { (g/bird) }\end{array}$ & 19.04 & 19.00 & 18.48 & 17.35 & 16.87 & 16.18 & 0.35 \\
$\begin{array}{l}\text { Feed } \\
\text { (g/birds) }\end{array}$ & 1254.88 & 1256.21 & $1247.30^{\mathrm{ab}}$ & $1231.00^{\mathrm{b}}$ & $1223.87^{\mathrm{c}}$ & $1217^{\mathrm{c}}$ & 4.89 \\
$\begin{array}{l}\text { Daily feed intake } \\
\text { (g/bird) }\end{array}$ & 44.82 & 44.86 & 44.55 & 43.96 & 43.71 & 43.46 & 0.73 \\
$\begin{array}{l}\text { Feed conversion } \\
\text { ratio }\end{array}$ & $2.35^{\mathrm{c}}$ & $2.32^{\mathrm{c}}$ & $2.41^{\mathrm{b}}$ & $2.53^{\mathrm{ab}}$ & $2.59^{\mathrm{a}}$ & $2.69^{\mathrm{a}}$ & 0.46 \\
$\begin{array}{l}\text { Feed efficiency } \\
\text { ratio }\end{array}$ & $1.92^{\mathrm{a}}$ & $1.92^{\mathrm{a}}$ & $1.88^{\mathrm{a}}$ & $1.78^{\mathrm{b}}$ & $1.75^{\mathrm{b}}$ & $1.69^{\mathrm{b}}$ & 0.29 \\
\begin{tabular}{l} 
Mortality (\%) \\
\hline
\end{tabular} & 5 & - & 5 & 10 & 15 & 15 & - \\
\hline
\end{tabular}

abcde Mean with different superscripts are significantly different $(\mathrm{P}<0.05)$

Table 3: Effect of delayed feeding on ileal digestibility coefficient of broiler chicks

\begin{tabular}{|c|c|c|c|c|c|c|c|c|c|c|c|c|}
\hline \multirow{2}{*}{$\begin{array}{l}\text { Fasted } \\
\text { period } \\
\text { (Hours) }\end{array}$} & \multicolumn{6}{|c|}{7 days old chicks } & \multicolumn{6}{|c|}{28 days old chicks } \\
\hline & DM & $\mathbf{C P}$ & $\mathbf{C F}$ & $\mathbf{E E}$ & Ash & NFE & DM & $\mathbf{C P}$ & $\mathbf{C F}$ & $\mathbf{E E}$ & Ash & NFE \\
\hline 12 & $80.5^{\mathrm{a}}$ & $76.02^{\mathrm{a}}$ & $60.0^{\mathrm{a}}$ & $65.7^{\mathrm{a}}$ & $67.2^{\mathrm{a}}$ & $70.0^{\mathrm{a}}$ & $88.56^{\mathrm{a}}$ & $84.2^{\mathrm{a}}$ & $75.0^{\mathrm{a}}$ & 82.0 & 69.3 & 72.2 \\
\hline 24 & $83.9^{\mathrm{a}}$ & $74.61^{\mathrm{a}}$ & $56.1^{\mathrm{a}}$ & $64.3^{\mathrm{a}}$ & $66.4^{\mathrm{a}}$ & $68.0^{\mathrm{a}}$ & $85.0^{\mathrm{a}}$ & $80.0^{\mathrm{a}}$ & $73.7^{\mathrm{a}}$ & 82.5 & 68.0 & 72.2 \\
\hline 36 & $78.3^{\mathrm{a}}$ & $72.03^{\mathrm{a}}$ & $54.6^{\mathrm{a}}$ & $60.0^{\mathrm{a}}$ & $66.0^{\mathrm{a}}$ & $68.0^{\mathrm{a}}$ & $82.0^{\mathrm{a}}$ & $79.4^{\mathrm{a}}$ & $73.0^{\mathrm{a}}$ & 80.3 & 68.5 & 71.6 \\
\hline 48 & $72.0^{\mathrm{b}}$ & $65.00^{\mathrm{b}}$ & $52.0^{\mathrm{b}}$ & $56.4^{\mathrm{b}}$ & $61.0^{\mathrm{b}}$ & $64.0^{\mathrm{b}}$ & $78.0^{\mathrm{b}}$ & $76.0^{\mathrm{b}}$ & $72.0^{\mathrm{a}}$ & 79.4 & 66.3 & 68.7 \\
\hline 60 & $68.4^{\mathrm{b}}$ & $60.05^{\mathrm{b}}$ & $47.4^{\mathrm{c}}$ & $52.0^{\mathrm{b}}$ & $60.8^{\mathrm{b}}$ & $60.0^{\mathrm{bc}}$ & $77.0^{\mathrm{b}}$ & $72.0^{\mathrm{b}}$ & $68.4^{\mathrm{b}}$ & 76.7 & 66.0 & 68.4 \\
\hline 72 & $62.0^{\mathrm{c}}$ & $54.64^{\mathrm{c}}$ & $42.2^{\mathrm{c}}$ & $45.5^{\mathrm{c}}$ & $56.0^{\mathrm{c}}$ & $58.0^{\mathrm{c}}$ & $77.0^{\mathrm{b}}$ & $70.0^{\mathrm{b}}$ & $66.6^{\mathrm{b}}$ & 75.1 & 66.4 & 68.0 \\
\hline SEM & 0.06 & 0.10 & 0.04 & 0.11 & 0.06 & 0.11 & 0.08 & 1.10 & 0.01 & 0.06 & 0.05 & 0.4 \\
\hline
\end{tabular}

abc Mean with different superscripts are significantly different $(\mathrm{P}<0.05)$ 